\title{
コンセントラ型ミル內の粒度分布に関する研究
}

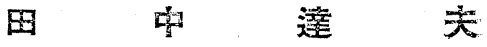 \\ (位沢大学エ、学部)
}

\author{
A Study on the Particle-distribution in a Concentra-type-mill \\ By Tatsuo TANAKA \\ (Faculty of Engineering, Kanazawa University)
}

The author determined the fineness of cement clinker being charged continuously to a concentra-type-mill, whose fine grinding room was devided into five segmental spaces by partition boards parallel to the axis.

The results were as follows:

1) The plots of the $0.088 \mathrm{~mm}$ oversize values $\mathrm{vs}$. the distances from the mill entrance showed that particle moving velocity through the mill was never homogeneous, but the mixing also in the opposite direction to the exit took place, especially in the vicinity of the entrance or just behind the screens.

2) Rittinger's law was approximately proved to be appliable assuming the moving rate of powder was nearly constant.

3) The exponential law was valid to the particle-distribution in the concentra mill, which was determined by means of a Wagner Turbidimeter.

The grinding-rate equation was derived by partial differentiation of the empirical exponential equation: from which the author described the procedure to estimate the most effective grinding condition.

\section{(1) 緒言}

セメント工業で多大の動力器消費する粉砕操作の合 理化は，製品の品質向上と共に重要な問題である。往 来放备工場で一般に便用されているコンパウンドチ ェーブミルに対して種々の改善汃考えられたのもこの 理团による。本報に調查の対象となつたコンセントラ ミルも文との1種で女り，普通のミルと異なる都分は

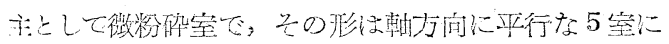
分敖され，比較的少小動力で，粉砕媒体による衝整と

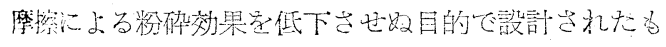

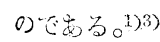

著者は現在の工場でセメントクリンカ仕上げ粉础中 のコンセントラ型ミルの汾猴状淠老調查与る目的で,

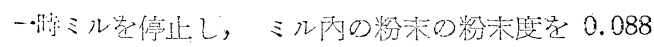
$\mathrm{mm}$ 篗, Blaine fineness meter 2 Wagner Turbidimeter 等により測定し, ミル內の粉执; 混合, 流動

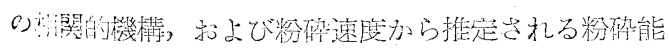

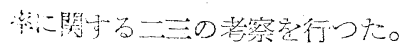

\section{(2) ミルの構造と試料採取法}

コン゙ヒントラ型ミルはいわけるコンパウンドミルの

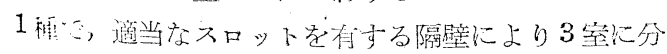
制される。I，II 至は普通のミルと同㥞に內部は中空

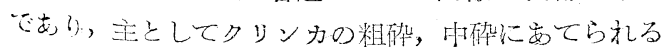
ように，使明媒体は比較的大なる銅球である。III 靠 ガコンセントラ型で㐫り前述のごとく微粉砕を目的と
している。概略の形式と大きさをFig.1に示すすしが して粉础媒体は $20 \times 30,12 \times 25 \mathrm{~mm}$ の 2 種類のミル ペップを用いている。

Fig. 1 Shematic diagram of the concentra-mi11

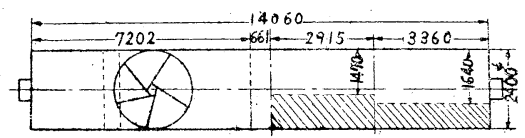

単住時聞当りの処理最は 15 ton $/ \mathrm{hr} の$ 連続供維，ミ

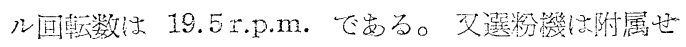
ず，い方ける open circuit た为る。

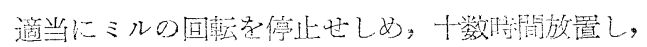
微粉末が洗穦しホ後ミル內に入り,入口上り約 $500 \mathrm{~mm}$

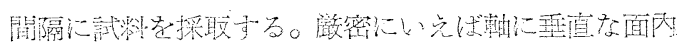

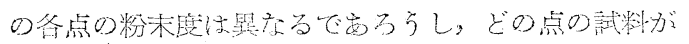

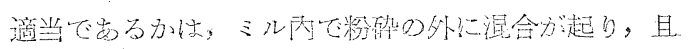

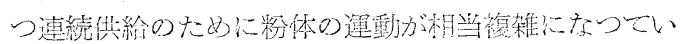

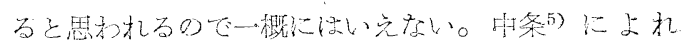

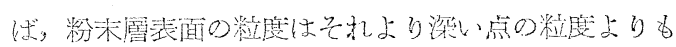
“粗いという結舁吕安り，この為著者は大体表面より数。

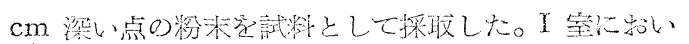

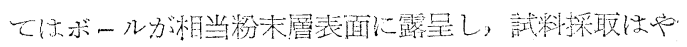

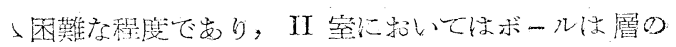

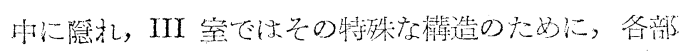
分について测定し得なかつたが、分㫼された1至につ 
いてのみ試料を採つた。これは当然ミルの軸に関して 各室対称の粉末度を示すと考える。I, II 室の粉末層 表面から上部の最大距離は Fig.1 に同時に示してま る。

\section{(3) 粉末度の測定亡結果の考察}

I, II 和よび III 室を通じ合計 28 箇所より㟫取し た試料に対して，前述の粉末度測定を行つた。以下䐜 次説明学る。

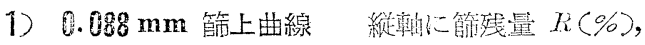

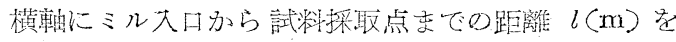

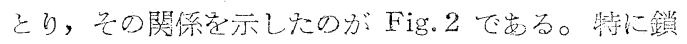
線は隔壁の位置を示与。

Fig. 2 Correlation of Residue for $0.08 \mathrm{~mm}$ sieve with the distance from entrance of mill $l$.

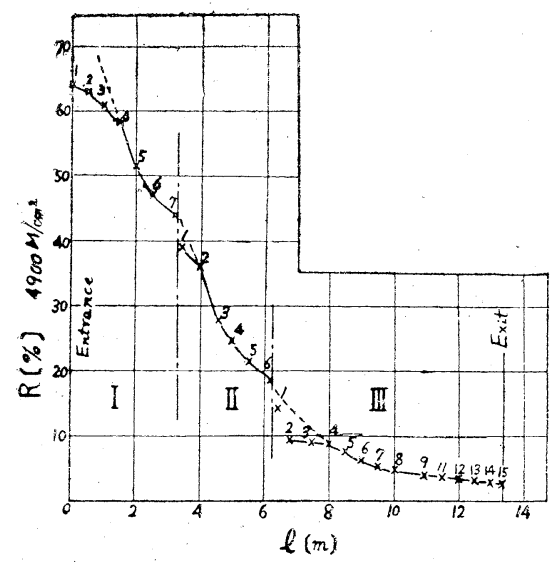

岂て管際にはミル大口，即ち図で $l=0$ の点では，

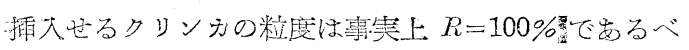
きにるか子小らず，Fig. 2 の示可值は $K=63.5 \%$ と いう非常に小なる值で第る。こ机から推察芑机ること は，石亳と共に选り达柰れたクリンカがミル入日から

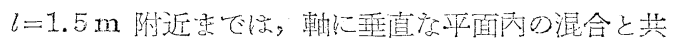

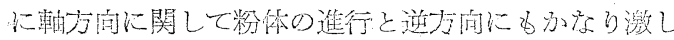

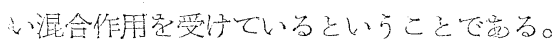

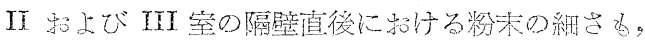

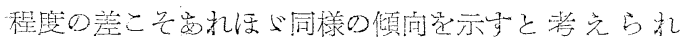

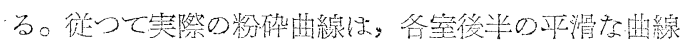

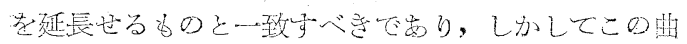

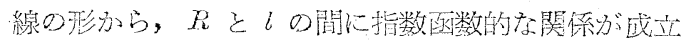
するよちである。この点に関しては後述の粒度分有に 関連与るからこつでは省略するが，とに㑲，ミル入日 爽は隔壁直後では混合作用が著しく，粉体のミル內の 流動機構学一層複雑化している。従つてミル內の粉末 の流動速度は決して一様ではない。一定方向に進行 する粒子閒の混合作用が，上述の著者の推定に從うと すれれ゙その機構に関する基礎的な研究が必要と思わ
れる。

\section{2) Blaine finene $s$ meter $\_$Wagner Turbid} imeter による比表面皘 $S\left(\mathrm{~cm}^{2} / \mathbf{g}\right) \quad$ Fig. 3 は各試 料について，空気透過法 (Blaine) と沈降法 (Wagner) により測定せる比表面積とし.と点綴した結果であ る。よく知られていることであるが，この雨方法によ る結果は一致せず，前者は後者の約 1.5 偕乃至 1.8 倍 の值を示す。この原因については種々の論諓があり， 爻この方面に関与る研究飞見られるがっ 本報では目的

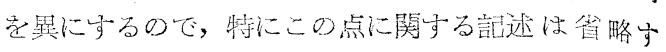
る。

Fig. 3 Specific surface vs. the distance from the entrance of mill.

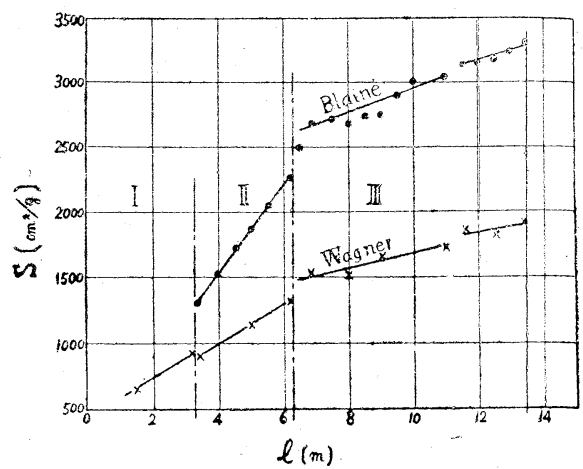

前項で述べたよりに：ミル內での粉体の流れが決し て一様でないために，各点の試料の比表再積の值は相 当散乱している。文粉末度が粗くなるほど，測定結果 の信頼性は少くなるが，何れのう法によつてもSを の関係は任心直線と見做して美支えないようである。

もし，粉末の流動速度がミル內学通じて一定なりと 伖定于れば， $l$ は粉觔に必要なエネルギ $E$ に比例し， このことから Rittinger の法則が誘導さ扎るがこ の仮定は前述のよ5に正しくなく，かつる大型ミルで

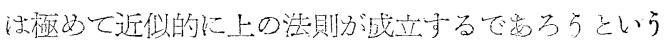
ことダでる。

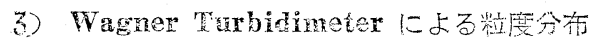

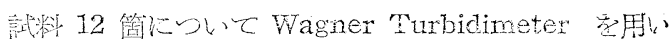

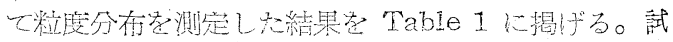
料番是の值は Fig. 2 ○各試料の点に示した番号を示 के

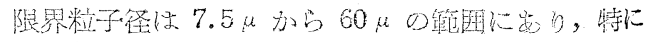
ストークス徍で表导机る。分散㷊は Ker̈osene，分散

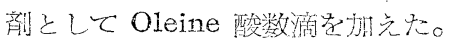

Rosin 等2) と中条らによつて提唱也号机る指数法 則は次式で或される。

$$
R=100 e^{-\pi i x^{\text {in }}}
$$

い亦，この式の雨辺の刘数足とり，移項して再び対数 をとれば

$\log (2-\log R)=\log k+\log \log e+n \log n$ 
Table 1

Residue $R \%$

\begin{tabular}{|c|c|c|c|c|c|c|c|c|c|c|c|c|c|}
\hline & & 7.5 & 10 & 15 & 20 & 25 & 30 & 35 & 40 & 45 & 50 & 55 & 60 \\
\hline I & 4 & 91.9 & 89.4 & 86.1 & 82.6 & 79.1 & 75.5 & 73.6 & 70.5 & 68.5 & 66.8 & 65.7 & 61.8 \\
\hline " & 7 & 89.5 & 84.2 & 77.7 & 72.8 & 69.4 & 65.7 & 62.8 & 60.4 & 57.3 & 54.7 & 52.8 & 51.2 \\
\hline II & 1 & 89.4 & 84.7 & 80.3 & 75.6 & .71 .7 & 66.8 & 63.9 & 61.1 & 58.2 & 55.7 & 52.5 & 50.3 \\
\hline "1 & 4 & 86.6 & 81.5 & 74.7 & 67.5 & 63.5 & 56.9 & 53.1 & 49.6 & 46.3 & 42.6 & 39.3 & 35.7 \\
\hline "y & 6 & 84.3 & 76.7 & 69.1 & 60.9 & 56.0 & 49.5 & 45.5 & 41.9 & 38.5 & 36.2 & 31.9 & 28.6 \\
\hline III & 2 & 82.1 & 73.8 & 64.5 & 56.6 & 49.7 & 42.4 & 38.2 & 33.0 & 29.6 & 26.1 & 23.0 & 17.9 \\
\hline "I & 4 & 84.7 & 73.6 & 63.8 & 55.4 & 49.0 & 41.4 & 37.0 & 33.0 & 29.6 & 26.7 & 22.5 & 18.9 \\
\hline "I & 6 & 81.8 & 70.5 & 59.6 & 50.8 & 43.6 & 36.0 & 31.0 & 27.5 & 23.6 & 20.7 & 19.1 & 15.6 \\
\hline "I & 9 & 78.6 & 67.4 & 59.4 & 50.7 & 43.9 & 36.0 & 31.7 & 26.3 & 21.7 & 18.8 & 15.6 & 12.1 \\
\hline "y & 11 & 77.6 & 66.8 & 56.3 & 46.3 & 40.2 & 33.8 & 30.0 & 24.2 & 21.4 & 18.3 & 14.9 & 11.2 \\
\hline$\%$ & 13 & 78.5 & 67.6 & 59.3 & 49.5 & 42.3 & 34.1 & 30.2 & 25.6 & 22.6 & 18.1 & 15.0 & 10.9 \\
\hline 11 & 15 & 76.5 & 65.3 & 55.4 & 46.0 & 39.4 & 32.8 & 28.7 & 24.9 & 20.6 & 15.8 & 14.5 & 10.9 \\
\hline
\end{tabular}

得る。彷つて測尝值 $D$ (Durchgang) かb $R$

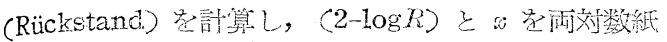

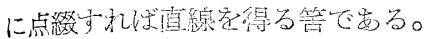

Fig, 4 世上还

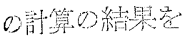
亦子当ので各 粉末につ1て2 れぞれの膚線條 岩得，ミル內の 粉末については 指数法斯力诚立 ナをことが要导 らかとなつ席。

こ虬吕の直線

Fig. 4 Logarithmic plot of 2-log $R$ vs. particle diameter.

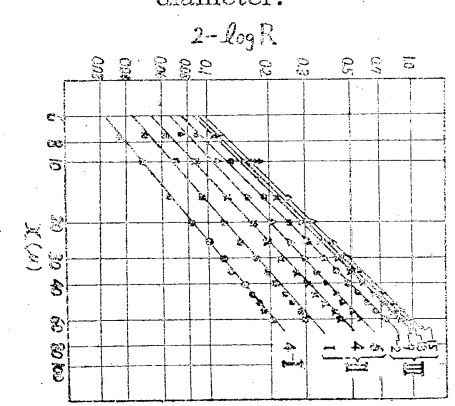

0傾斜加与 (1)

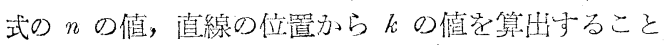
ができる。nの值は大略1に近い做を示し，中条の

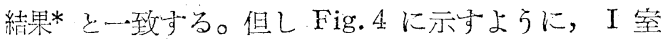
加ら III 室に至るに徉い, 即方粉末が漱次細くなるに

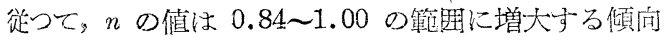
にありっ一般にボールミルに抬ける結果と反対の傾间

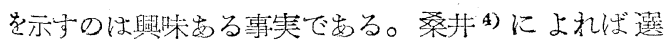
粉機の附属也るミルでは細くなるにつれて $n$ 艻増大 守る傾向があるとされているが，本報で述べるコンセ ントラ型ミルには選粉機は附属していない。この点に 関しては更に精密な帮験が必要と思う。

著者は最刻かる大大型ミル全体定通じて成立与る指 数法則を誘導与れてばミルの設語に便利で女ると考え， $k$ の值と $l$ の関係走連続函数で表せるよう武みたが， これは成功しなかつた。この理由として第1に考えら れることは各公によりnの值独ること，第 2 に前述 のようにミル內の流動機構が複雑でまり, 粉础の外に 三次元的な混合作用の存在守ること, 预上びウ条子 指摘されているごとく，ミル各位の相体の形状，寸法

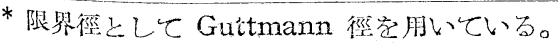

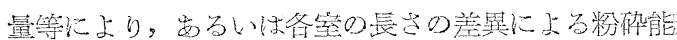

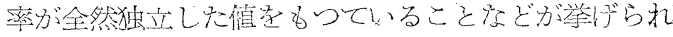
高のだる。

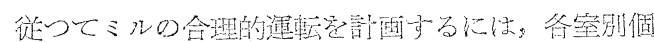

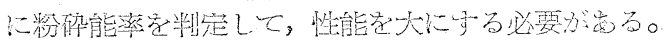

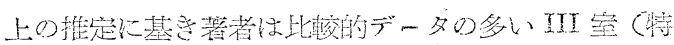

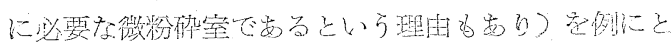

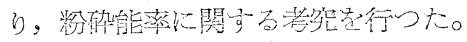

Fig. 5 Left: Plot of $h$ vs. $L$ for the III-room Right: Logarithmic plot of $(k-c)$ vs. $L$ for estimating $m$.

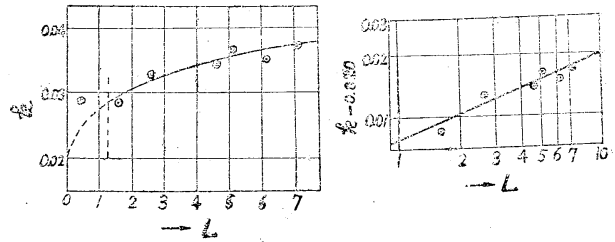

Fig. 5 左図は第 III 空のk の值を，隔壁の位置を 原点として測定せる距離 $L(\mathrm{~m})$ に対して点紴した綕 果で㐫る。岁きらかに綎軸に截片を有する扰物線と考 えら礼る。

助ち Fig. 5 に示される拋物線は一般に

$$
k=c+p L^{m}
$$

で表すことが出来る。こ〉火 $0 ， p$ は恒数と考える。 こ〉で注意すべきほ隔壁に近い点がはなはだしく扰物 線から外れているが，前に誰述したように隔壁真後に は (約 $1.5 \mathrm{~m}$ ) 粉砕は不連繶之考学て差支えないの

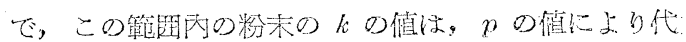

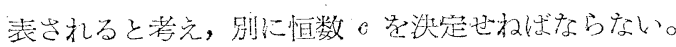

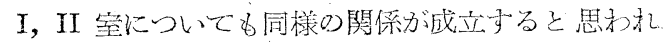
るので，一般にミル各䕟に対して

$$
R=100 e^{-\left(c+p L^{m}\right) x^{2 n}}
$$

なる指数法則が成立する。

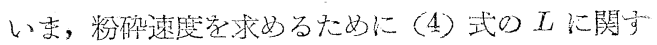
る偏微分学計算与ると 


$$
\begin{aligned}
(\partial R / \partial L)_{x} & =-x^{n}\left(p m L^{m-1}\right)\left(100 e^{\left.-\left(c+p L^{m}\right) x^{n}\right)}\right. \\
& =-x^{n} \cdot p \cdot m L^{m-1} \cdot R \quad \cdots \cdots \cdots \cdots \cdots \cdots(5)
\end{aligned}
$$

$x^{n} p=K$ と稼けば

$$
(\partial R / \partial L)_{x}=-K m R / L^{1-n}
$$

在得る。即ち昐磪速度は $R$ に比例し， $I^{x-m}$ に逆比

例与ることになる。

$$
m=1 \text { ない゙, } L^{1-m}=1 \text { となり }
$$

$(\partial R / \partial L)_{x}=-K \cdot R$.

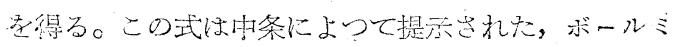

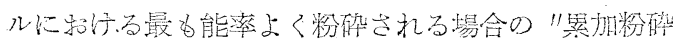
の法則" と同一型式の犻是とる。

但しミル円の粉体の流れ速度が一㥞でないる，ミ

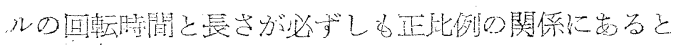

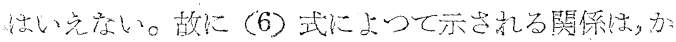

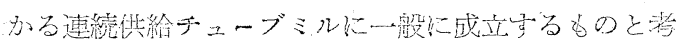

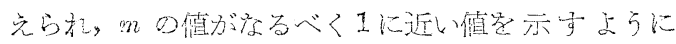

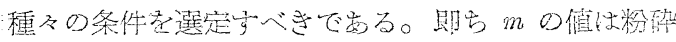

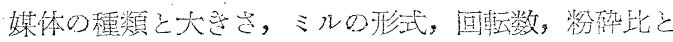

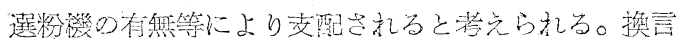

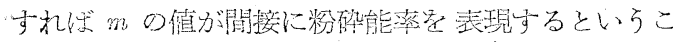
とがでる。

Fig. 5 右図は, III 至について常数 $c$ 党求め, (k一

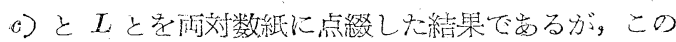
直線の傾意から $m=0.43$ 尘得，著者の推諭老以つて 寸机ば，必ずしも性能がよいとはいえない。この原因 については，志ず粉伜媒体が適当でないこと，次に回 転数が果して最適なる粉体条件を与えるかどらかとい らことで咘る。

彷来の理諭入は笑蛤的研究の結果，粉砕に適当な中 空円筒ミルの最適回転数は次式で表される。

$$
n=32 / v \bar{l}
$$

こ、にDはミルの怪 (m) で员る。本報のミル回 鞋数子低心゙この式定渵足している。

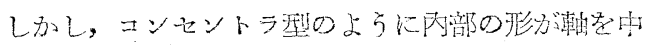

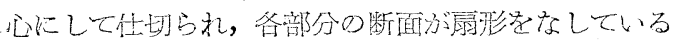
場合，果して粉砕媒体爻は粉末の㖶動は中空山筒の晹 合と全々同裳に技光るかどうか，少くとも(8) 式に
より示忠れる最適回転数が，かつる特殊構造のミルに 対しても適朋されるものかどらかははなはだ疑わし く，又與昧深いものが岕る。著者はこの点に閣して将 来明快な解浃苦つけたいと考えている。

\section{(4) 結訔}

著者は現在工場で作業中のコンセントラ型ミルに対 して，ミル內の粉研状沉を誠查するため，種及の粉末 度索測定した結果，次の业項について考察した。

1) $0.088 \mathrm{~mm}$ 節残暴 $R$ とミル大日からの距離 $l$ の哭係から，ミル內の粉未の流れがー様でなく，特に

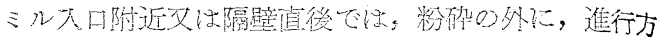

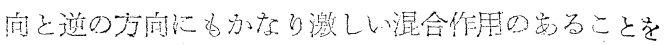
推定し充。

2) Blaine fireness meter 爻情 Wagner

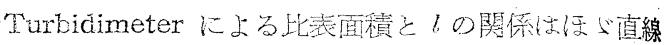

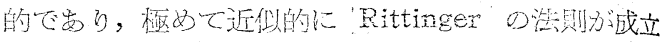
当ること加分つた。

3) Wagner Turbidimeter による粒度分布の結果 からミル內の粉末については指数法則が成吉すること があきらかとなつた。文洗勘との他の複雑な雪情のた めにミル全体について成立する式は誘導できないが， 各至については広い意味て指数法則のkの值と $L$ と が関連し，征つてこの式から粉确速度が誘導さ扎た。 この結果ミルの各空に和ける粉砕能率の判定が可能と なりその例㺼示した。

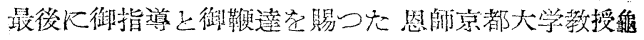

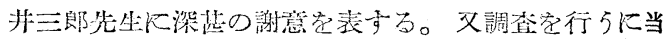
り種及の御好意と御援助を与光られた小野时セメント

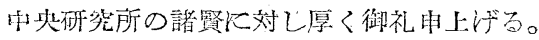

$$
\text { 参考文 献 }
$$

1) Naske, V.D.I., 1935, 78, 1275

2) Rosin \& Rammler, Zement, 1983, 31

3) Schmidt, ibid., 1933, 41,565

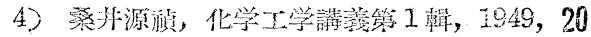

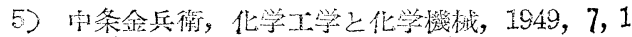
(10/20/51 要附)

\section{新利紹分}

秋田大学教授野口清著

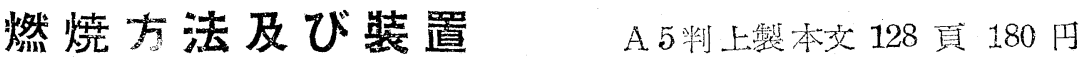

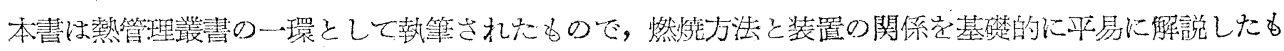

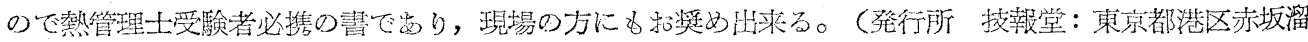
池 5 振替口座東京 10 番) 協会宛县込め㳊次いたします。 